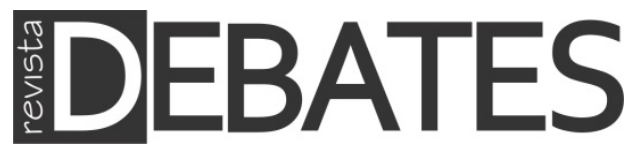

\title{
Política e juventude: participação política dos jovens do Sul do Brasil
}

\author{
Politics and youth: political participation of young people of the South \\ of Brazil
}

\author{
Renata A. de Oliveira \\ Carla S. Ayres \\ Jaqueline Resmini Hansen \\ Julian Borba
}

\section{Resumo}

Este artigo apresenta os resultados da pesquisa Democracia, midia e capital social: um estudo comparativo da socialização de jovens do Sul do Brasil, realizado nas três capitais da região, entre 2015 e 2016, com alunos do ensino médio de escolas públicas e privadas escolas. Focalizamos nossa análise na participação política, para verificar quais seriam os determinantes e relaçôes das modalidades de participação online e offline. A principal hipótese que permeia este estudo é que há uma maior disponibilidade para a participação on-line e modalidades off-line não convencionais. Além disso, também discutimos acerca dos determinantes das diferentes modalidades de ação através de análises descritivas e multivariadas de natureza comparativa e individual entre cidades. Os resultados mostraram que, embora não haja preferência pelas açóes diretas e pelo ambiente on-line, há um fortalecimento mútuo entre elas e uma convergência entre modalidades e ambientes.

\section{Palavras-chave}

Participação Política; Juventude; Porto Alegre; Florianópolis; Curitiba.

\section{Abstract}

This article brings partial results of the research Democracy, media and social capital: a comparative study of political socialization of the young people of the South of Brazil conducted in the three capitals of the region, between 2015 and 2016, with high school students from public and private schools. We focus our analysis on political participation, to verify what would be the determinants and the relations of online and offline participation. The main hypothesis that permeated this study is that there is a greater willingness to participate online and for non-conventional off-line modalities. In addition, we also discuss the determinants of different modes of action through descriptive and multivariate analyzes, making comparative analyzes and individual models between cities. The results showed that, although there is no preference for direct actions and the online environment, there is a mutual strengthening between them and a convergence between modalities and environments.

\section{Keywords}

Political Participation; Youth; Porto Alegre; Florianópolis; Curitiba. 


\section{Introdução}

A participação política é vista como uma atividade em que os cidadãos colocam suas vozes no espaço público para atingir suas múltiplas direçóes (VERBA, SCHLOZMAN e BRADY, 1995). Por conta disso, tornou-se um dos temas centrais das pesquisas na Ciência Política, particularmente, no que tange as modalidades e os fatores que levam os indivíduos a se envolverem politicamente.

A literatura tradicional, que se concentra no comportamento participativo dos cidadãos, classifica as atividades de participação pelo menos em duas frentes. De um lado, as chamadas ações 'convencionais', como: participar de discussões políticas, votar, trabalhar em campanhas eleitorais, ser membro ativo de partidos políticos, candidatar-se, ocupar cargos públicos, entre outros (MILBRATH, 1965; VERBA e NIE, 1972). De outro, as ditas formas de engajamento contestatório, ou seja, as atividades participativas vinculadas à atuação nos movimentos de protesto, ou 'formas não convencionais' que envolvem exemplos como os boicotes, ocupaçóes, abaixoassinado, manifestaçôes ou passeatas. (DELLA PORTA, 2003; NORRIS, 2002).

Ao que tange a realidade latino-americana, estudos revelam estabilidade ou até mesmo declínio de diferentes modalidades contestatórias dependendo do país em questão (RIBEIRO e BORBA, 2015). Com base nos dados produzidos pelo Latinobarômetro, no caso específico do Brasil, verificou-se que manifestaçôes, por exemplo, apresentaram forte declínio, passando de uma adesão de 27,1\% em 1995 para $14,0 \%$ em 2007. De modo geral, os achados mostram que a participação dos brasileiros em protestos está associada à maior escolaridade e interesse prévio por política (BORBA e RIBEIRO, 2010).

Os ciclos de protestos iniciados em junho de 2013, no Brasil, trouxeram novas configuraçóes ao cenário participativo ao confrontar algumas ideias estabelecidas na literatura, e isto passou a inquietar os pesquisadores e pesquisadoras da área. Como por exemplo, questionaram a ideia dos protestos serem associados a contextos de crise, revelaram a adesão de segmentos e localidades com pouca tradiçáo de repertório contestatório, impressionaram com a velocidade da proliferação das manifestaçóes, e sobretudo, destacaram-se pela alta participação de jovens mobilizados massivamente pelas redes sociais.

Cenários como este revelam outra frente que tem sido explorada nos últimos anos pelas pesquisas, que é o uso das mídias digitais, em destaque, a internet, como meios e espaços de participação política, a chamada participação online ou eparticipação (BABBER, 2003; GIBSON e CANTIJOCH, 2013; NORRIS, 2001). O uso dos meios de comunicaçáo em massa, a partir do século XX, como telefone, 
rádio, televisão, cinema e, mais recentemente, as mídias digitais, constitui outra importante característica das sociedades modernas. Os meios de comunicação atuam como facilitadores do processo comunicativo inerente ao ser humano, já que são "tecnologias que expandem a comunicação no tempo, no espaço e na modalidade" (HJAVARD, 2012, p. 66). Portanto, as mídias são lugares com linguagens próprias, que os indivíduos mobilizam para decodificação, interpretação e interação com o mundo, e por consequência, tornam-se espaços de ação política (MEYROWITZ, 1993; MARTINO, 2015).

Diante destas características, a web tem tomado um espaço expressivo nas sociedades. De acordo com o relatório da International Telecommunication Union (2014) 40,4\% da populaçấo mundial já tinha acesso à rede mundial de computadores em 2013. No caso brasileiro, o relatório do Comitê Gestor da Internet (2013) afirma que $51 \%$ da populaçáo estava conectada nas modalidades móvel e fixa, já a Pesquisa Brasileira de Mídia-2015 (BRASIL, 2014) aponta que 37\% da população tem acesso diário a web. No que tange a população conectada, a Pesquisa Brasileira de Mídia2015 (BRASIL, 2014) mostra que o internauta brasileiro passa em média 04h 59 min conectado durante a semana e $04 \mathrm{~h} 24 \mathrm{~min}$ nos finais de semana. Esta mesma pesquisa indica que entre o extrato mais jovem (16 a 25 anos) a média sobe para $05 \mathrm{~h} 51 \mathrm{~min}$ na semana e $05 \mathrm{~h} 25$ nos finais de semana. Nesse sentido, os jovens destacam-se por serem os principais usuários do espaço online, e por isso, passaram a ser objetos de análises das recentes pesquisas sobre participação política (BRASIL, 2014; CGI, 2013; ITU, 2014).

Os estudos que relacionam juventude e participação política mostram que os jovens brasileiros apresentam uma tendência a se envolver mais em açôes de protesto, principalmente aquelas em que os custos são mais altos (OKADO e RIBEIRO, 2015). Seguindo essa tendência, o presente artigo busca complementar esses estudos ao trazer os resultados parciais da pesquisa intitulada Democracia, mídia e capital social: um estudo comparativo de socialização política dos jovens do Sul do Brasil, realizada pelo Núcleo de Pesquisa sobre a América Latina (NUPESAL) da Universidade Federal do Rio Grande do Sul (UFRGS) aplicada nas três capitais do Sul do país, Curitiba, Florianópolis e Porto Alegre, entre 2015 e 2016, com estudantes de ensino médio de escolas públicas e particulares. Nosso objetivo é verificar quais são os determinantes das modalidades de participação online e off-line (convencionais e não convencionais) dos jovens das capitais da região Sul do Brasil. O principal intuito é contrastar os resultados do estudo com o que a literatura tem 
apontado como os aspectos da participação política dos jovens, ou seja, que existiria uma maior disposição para a participaçáo online e para as modalidades off-line náo convencionais. Para tanto, utilizamos análises descritivas e multivariadas, com modelos para as três capitais conjuntamente e de maneira individual.

Deste modo, o artigo apresenta quatro sessões que além desta introdução discutem: i) aspectos empíricos e teóricos acerca das modalidades de participação política off-line e online; ii) uma discussão mais detida sobre juventude e participação política no Brasil; iii) no item os condicionantes da participação dos jovens nas capitais do sul do Brasil apresentamos e discutimos os resultados da pesquisa; iv) por fim apresentamos alguns apontamentos conclusivos e indicativos de refinamentos analíticos futuros.

\section{Participação Politica Off-line e Online}

Como apontado anteriormente, a categorização tradicional das modalidades de participação concentra-se na distinçáo entre "participação convencional" e "não convencional". Estudos tem mostrado que diferentes fatores são importantes para explicar o engajamento político dos indivíduos. Em outras palavras, tanto as motivaçóes individuais, os aspectos cognitivos e atitudinais, como os sócio demográficos e contextuais são significativos, indicando que o fenômeno é multidimensional (RIBEIRO e BORBA, 2015; VERBA, SCHLOZMAN e BRADY, 1995). Nesse sentido, diferentes trabalhos têm se debruçado na investigação sobre quais seriam os possíveis fatores que impulsionam o envolvimento individual nas diferentes modalidades de participação. Com destaque para as contestatórias, que estão relacionadas aos novos repertórios políticos, em geral, aponta-se quatro propulsores do engajamento: 1) descontentamento individual (GURR, 1970); 2) os recursos individuais e coletivos, como tempo livre, renda, escolaridade e as habilidades cívicas (VERBA, SCHLOZMAN e BRADY, 1995); 3) a tese das mudanças culturais e valores pós-materialistas (INGLEHART E WEZEL, 2005); e por fim, 4) as questóes identitárias, sendo a mais relevante delas, a orientação ideológica individual (DALTON e SICKLE, 2005).

$\mathrm{O}$ fato é que uma forte agenda de pesquisa se abriu no intuito de investigar se estas duas formas de participação apresentam elementos condicionantes de convergência ou divergência. Ou seja, os indivíduos engajados em modalidades convencionais se envolvem também em modalidades não convencionais? (BORBA e RIBEIRO, 2011). 
A fim de testar a existência de convergência ou divergência de distintas modalidades de participação na América Latina, Ribeiro e Borba (2015) lançaram mão de dados do WVS de 2006 em especial sobre Argentina, Brasil, Chile e Uruguai. Em que pese os testes realizados pelos autores apresentarem capacidade explicativa de variáveis de cultura política e de "centralidade" para os quatro países, os índices de pós-materialismo obtiveram capacidade preditora apenas para Brasil e Chile; em relação especificamente à tese da convergência o que se verificou foi relação convergente entre participação convencional e não convencional apenas para Argentina e Brasil.

Com relação às formas de ativismo online, as novas tecnologias de informação e comunicaçáo atuam de maneira complexificada, em um movimento duplo. De um lado, a rede reforça a participação daqueles que já estão engajados nos espaços offline, abrindo novos horizontes participativos para esses indivíduos, indicando para a influência da experiência off-line na conduta online (LIVINGSTONE, 2011). Por outro lado, a web também é capaz de mobilizar novos atores, principalmente através do, já explicitado, acesso a gama diversificada de informação (HAFNER-FINK e OBLAK ČRNIČ, 2014; NORRIS, 2001; MARGETTS, 2013).

Essas duas forças resultam em aspectos distintos que caracterizam as atividades políticas no ambiente online. Assim, se por um lado, as modalidades de ação online replicam as presenciais e integram os dois ambientes, principalmente através do fortalecimento das modalidades de protesto. Por outro, a popularização do acesso, a interação com a internet e o surgimento das redes sociais digitais trazem consigo uma certa independência do ciberespaço, que se reflete em atividades que apesar de muitas vezes serem mais passivas se constituem como puramente online, sendo assim um tipo distinto de ativismo (GIBSON e CANTIJOCH, 2013; HAFNER-FINK e OBLAK ČRNIČ, 2014; NORRIS e CURTICE, 2006; OSER, HOOGHE e MAREN, 2013; VALENZUELA, 2014).

Deste modo, as características centrais da internet, de ser um novo repertório para os já ativos e um repertório possível para os inativos, e um ambiente que apesar de independente se integra ao off-line, leva a percepção da participação online como multidimensional e multidirecional, assim como a presencial. Isto significa que não apenas a dimensão tecnológica explicaria o engajamento digital mas também, o próprio ativismo off-line, bem como os recursos (tempo, dinheiro e habilidades), além dos conhecimentos e competências. Além disso, a participação nos meios digitais procura influenciar náo apenas as decisóes dos governantes e dos 
agentes públicos, mas também as percepçóes da sociedade e seus modos de vida (BEST e KRUGER, 2005; GIBSON e CANTIJOCH, 2013; NORRIS e CURTICE, 2006). Portanto, a participação política online pode ser definida como uma atividade personalizada e individual, que ao expor sua mobilização ativa as redes sociais as quais está conectado, aumenta a conscientização acerca de problemas sociais e políticos e, assim, atua como um local para exercer pressóes sociais ou políticas para resolução destes problemas (THEOCHARIS, 2015).

Diante das proximidades entre as noçôes de participaçáo off-line e online, diversas pesquisas foram realizadas com intuito de descobrir se o perfil do ativista digital seria semelhante ao presencial. Pesquisas em diferentes contextos online demonstram que em linhas gerais, os indivíduos que utilizam da internet para participação tendem a ser mais jovens (BRUNDIDGE e RICE, 2009; HAFNERFINK e OBLAK ČRNIČ, 2014; MOSSBREGER, 2009; NORRIS, 2001; NORRIS e CURTICE, 2006; OSER, HOOGHE e MAREN, 2013), mais educados (BRUNDIDGE e RICE, 2009; HAFNER-FINK e OBLAK ČRNIČ, 2014; HANSEN, 2016; MESQUITA e CANTONI, 2016; MOSSBREGER, 2009;NORRIS, 2001; NORRIS e CURTICE, 2006), pertencentes a niveis socioeconômicos mais elevados (BRUNDIDGE e RICE, 2009; MOSSBREGER, 2009; NORRIS, 2001; SCHEGEL, 2009), melhores informados (BRUNDIDGE e RICE, 2009; HANSEN, 2016; NORRIS, 2001; NORRIS e CURTICE, 2006), portadores de recursos e habilidades cívicas (BEST e KRUGER, 2005; HANSEN, 2016) e já ativos em modalidades presenciais (BEST e KRUGER, 2005; BRUNDIDGE e RICE, 2009; HAFNER-FINK e OBLAK ČRNIČ, 2014; OSER, HOOGHE e MAREN, 2013).

Diante das relaçóes convergentes entre os ambientes presenciais e digitais (DAHLGREN,2005), bem como, com o surgimento de redes sociais digitais capazes de propiciar uma interação entre o ativismo presencial e a e-participação (VALENZUELA, ARRIGADA e SCHERMAN, 2012; VALENZUELA, 2014) e a emergência de cidadãos ativos em ambos os espaços, surge um movimento para compreender quais modalidades, institucionais ou de protesto, poderiam ser fortalecidas pelo uso da internet. Especificamente no contexto brasileiro, Mesquita e Cantoni (2016) e Hansen (2016) buscaram descobrir os condicionantes do ativismo 
online e a sua relação com a ação presencial, usando de bases de dados distintas ${ }^{1}$. Seus resultados apresentam aspectos semelhantes uma vez que ambos mostraram que o acesso à educação é o principal preditor do ativismo online (assim como do off-line), bem como, encontraram evidências que existe uma convergência entre os ativistas digitais e presenciais. Embora os primeiros pesquisadores tenham encontrado que os meios eletrônicos se aproximariam mais das modalidades institucionais e a segunda pesquisa, descobriu um fortalecimento mútuo entre as açóes contenciosas e institucionalizadas, ainda assim é possível concluir que em ambos os casos o perfil não se diferencia entre onlines e off-lines, indicando que a rede mundial de computadores tende a se apresentar com mais força como um novo repertório entre os já engajados, embora nenhuma das pesquisas descarte que ainda existe um potencial democrático nas redes.

Apesar dos resultados semelhantes acerca da não homogeneidade do impacto das mídias digitais as pesquisas avançam em caminhos diferentes. Os dados analisados por Hansen (2016) demonstram que apesar da covariação entre ativismo online e presencial, existe uma tendência dos indivíduos que se sentem ineficazes politicamente procurarem na internet um local para ecoar a sua voz. Com isso, a pesquisadora infere que as tecnologias digitais têm se apresentado como uma ferramenta de ação capaz de atrair, mesmo que a longo prazo, indivíduos antes desiludidos com o sistema participativo. Os dados analisados por Mesquita e Cantoni (2016), por sua vez, mostram que os cidadãos ativos - tanto na participação em modalidades presenciais como nas digitais - confiam mais nas instituiçóes democráticas, bem como o ativismo atua no sentido de aumentar esta confiança. Diante disto, o engajamento online favorece atitudes em relação ao sistema político, entre elas o apoio a democracia.

Dadas estas particularidades, através desses novos espaços, o indivíduo adquiriu a possibilidade de produzir e compartilhar informaçóes, principalmente, na web, funcionando esta como ferramenta para o engajamento e como um local para visibilidade de temas e demandas (MEYROWITZ, 1993; VALENZUELA, 2014; TEOCHARISE, 2015). Essa outra faceta tem alterado a forma de se olhar para a participação política, não no sentido de excluir as modalidades tradicionais, mas sim

\footnotetext{
${ }^{1}$ A pesquisadora Jaqueline Hansen (2016) utiliza da base de dados do Latin American Public Opinion Project - LAPOP do ano de 2012. Os pesquisadores Nuno Mesquita e Stefania Cantoni (2016) utilizam dos dados da pesquisa "25 anos de Democracia no Brasil".
} 
de repensar os novos repertórios e espaços de mobilização política, principalmente, analisar as características de seus principais agentes, no presente caso, os jovens.

\section{Juventude e Participação Politica no Brasil}

Uma das características da sociedade moderna diz respeito a percepção da juventude como uma etapa da vida com características próprias e com modos específicos de interação, atuação e reação ao mundo (CASSAB, 2011). Neste sentido, a juventude diz respeito a uma categoria socialmente produzida, a qual possui um recorte etário, no Brasil dos 15 aos 29 anos, sendo caracterizada como uma fase de transição que se finda com o casamento e entrada para o mundo do trabalho, típicas características da vida adulta. Portanto, a partir deste entendimento é plausível que se estabeleça um debate sobre os modos de participação da juventude em comparação com as formas de participaçáo dos adultos. Embora alguns estudos recentes apontem para certo declínio do engajamento político da juventude focados, principalmente, no baixo comparecimento eleitoral (DALTON, 2009; PUTNAM, 2001), existem abordagens que procuram entender se a participaçáo da juventude não estaria se direcionando para outros espaços, bem como, procuram compreender como diferentes estruturas sociais influenciam no comportamento político dos jovens.

Uma das abordagens nesse sentido é a teoria do pós materialismo, para a qual os valores dos indivíduos mudariam em função do processo de modernização econômica da sociedade. Considerando o contexto das sociedades desenvolvidas, identificam que a cada mudança de geração os indivíduos tenderiam a se preocupar menos com questóes materiais e mais com questôes pós-materiais (INGLEHART e WELZEL, 2005; DALTON, 2009; NORRIS, 2003). Em tais contextos, os dotados de valores materiais são os mais ativos nas modalidades eleitorais e também mais velhos, e os dotados de valores pós-materiais são mais jovens e mais ativos nas modalidades diretas e contenciosas. Portanto, não é que a participação juvenil esteja em declínio, e sim que este grupo social focaliza sua ação em modalidades diferentes (INGLEHART, 1977; RIBEIRO, 2011).

Assim, somando-se às discussóes dos autores acima, Pippa Norris (2002 e 2003) propóe que se ajustarmos o foco perceberemos que a juventude apresenta uma apatia pelas formas eleitorais, institucionalizadas e formalizadas de ação política, no entanto, ela tem crescido qualitativamente em açóes orientadas para causas específicas, que são espontâneas e contenciosas, e se aproximam mais do associativismo. Diante disso, os pesquisadores filiados a perspectiva da transição 
geracional defendem que o declínio do ativismo eleitoral e crescimento do ativismo de protesto estaria atrelado a construção de uma cidadania crítica.

Norteados por esta ideia que indivíduos de diferentes geraçôes teriam predisposiçóes participativas distintas moldadas, em grande parte, pelo contexto de modernizaçáo econômica e social em que foram socializados, Ribeiro e Ayres (2011), pensam as diferenças participativas entre os estratos populacionais brasileiros utilizando dados produzidos pelo projeto World Values Survey no ano de 2006. A hipótese era de que os estratos populacionais mais jovens, que viveram seus períodos mais suscetíveis de socialização sob a vigência de instituiçôes democráticas, manifestassem uma disposição mais engajada, entretanto os resultados não foram os esperados: 1) no que tange as formas convencionais de participação (sindicatos e partidos), os mais jovens, em comparação com os mais velhos, são menos envolvidos; 2) Nas modalidades de protesto ou não convencionais os testes indicaram na maioria dos casos a inexistência de relacionamento significativo, mostrando que estratos com menos e mais idade não se diferenciam em termos desse ativismo contestatório. Deste modo, como o jovem brasileiro não é mais engajado que as geraçóes subsequentes, a participação não estaria sofrendo os efeitos de uma mudança geracional e portanto, no Brasil, a mudança de contextos não estaria favorecendo que entre a juventude surgisse uma cidadania mais crítica.

Um outro grupo de pesquisas, com abordagens filiadas à teoria da socialização política advogam a importância das estruturas e processos, que se estabelecem nos ambientes familiar e escolar, no comportamento político dos jovens. Família, escola e religião seriam instituiçóes responsáveis por criar um ambiente favorável a uma atitude participativa, que resultaria na construção dos atributos individuais necessários a participação política - a saber, recursos e motivaçôes (VERBA, SCHOLZMAN e BRADY, 1995).

Entretanto, os efeitos dos ambientes socializadores não afetam a participação juvenil de maneira homogênea. De acordo com Fuks (2011) esses efeitos podem ocorrer de maneira direta, indireta ou tardia dependendo da instituição. Os efeitos da família sobre a participação dos jovens são diretos quando os pais são engajados, embora, este engajamento combinado com condição socioeconômica e escolaridade dos pais afetem a participação dos filhos indiretamente através da motivação para aquisição de informação política. A instituição escolar também apresenta um efeito indireto por meio do estímulo do interesse por política através da fomentação ao conhecimento político. As instituiçóes religiosas, por sua vez, apresentam também um 
efeito indireto ao criar um "estoque" de disposição a participação através da ação cívica. Por fim, a combinaçáo destes ambientes politizados com a condiçáo socioeconômica do indivíduo, levam a aquisição de recursos e habilidades que são decisivos no processo de participação política na vida adulta, caracterizando um efeito tardio. Os resultados do seu estudo realizado junto aos jovens de Belo Horizonte mostraram que a participação dos pais, principalmente em modalidades associativas, possui um efeito direto na participação dos jovens através da transmissão intergeracional. Entretanto, a pesquisa também mostra que a família, assim como a escola e o pertencimento a entidades religiosas, possui um efeito indireto, ou seja, estas instituiçóes atuam na construção das motivaçóes individuais - conhecimento e interesse por política, e eficácia subjetiva - que se refletem em uma atitude mais propensa a participação. Por fim, as instituiçôes familiar, escolar e religiosa também atuam tardiamente na participação política através da estruturação de um estoque de estímulos que se traduzem em motivaçóes positivas para açóes políticas na vida adulta.

Neste mesmo caminho a pesquisa de Krischke (2004), realizada através de uma amostra representativa da juventude brasileira, mostra a centralidade dos recursos e motivaçóes individuais na participação juvenil. De acordo com esta pesquisa, escolaridade, renda, eficácia subjetiva, interesse por política e vinculação partidária são importantes preditores das formas convencionais de participação entre os jovens. Já nas modalidades contenciosas renda, escolaridade, eficácia subjetiva, ser mulher e residir no local a pouco tempo são os principais condicionantes entre os jovens.

Diante da importância dos efeitos de socialização na participação política dos jovens, traduzidos, principalmente, na construçáo dos atributos e motivaçóes individuais e na centralidade da educação na explicação da participação política entre os brasileiros levaram Okado e Ribeiro (2015) a questionar a importância da condição juvenil nos atos participativos. Os pesquisadores encontraram que as diferenças entre jovens e adultos nos processos participativos são explicadas pela ideia de ciclos de vida, que é decorrente da perspectiva da socialização política, um vez que esta advoga que as formas de engajamento podem se alterar no decorrer da vida ou serem determinadas pela aquisição de recursos individuais (KINDER, 2006; FLANAGAN, 2013). Portanto, os indivíduos atuariam politicamente de diferentes modos por conta do período da vida que se encontram, assim os jovens seriam mais ativos nas modalidades de protesto pois, como teriam menos a perder estariam mais dispostos a pagar os custos mais altos de ações diretas. Com a inserção no mercado de 
trabalho, o casamento e por consequência, a mudança para o ciclo adulto os indivíduos passam atuar mais em modalidades convencionais e menos custosas.

Portanto, Okado e Ribeiro (2015) mostram que entre os brasileiros o envolvimento em atividades eleitorais é uma atividade típica de adultos e as atividades contestatórias uma açáo da juventude, sendo que os eventos relacionados ao ciclo de vida são responsáveis por mediar essa relação, de modo que quando o cidadáo adentra a vida adulta, sua centralidade social o leva a ativar repertórios que no ciclo juvenil não lhe eram típicos. Segundo os autores,

\begin{abstract}
ao assumir novos papéis dentro da estrutura social os indivíduos passam a ter acesso a novos repertórios de socialização, que por sua vez condicionam a sua participaçáo, remodelando-a para se adaptar ao novo contexto no qual se insere, como é o caso da participação convencional. Aqueles que ocupam posiçôes centrais no interior da sociedade possuem mais chances de se envolveram em atividades de campanha eleitoral, fato possível apenas com o ingresso na vida adulta. Por sua vez, ao atingirem a maturidade e constituírem dependentes, a participação não convencional se torna mais custosa, na medida em que se coloca em jogo a manutenção de sua família e de sua posição social (OKADO e RIBEIRO, 2015, p. 75).
\end{abstract}

Vale destacar que os estudos acima se inserem num conjunto de trabalhos delineados sobre o que chamamos de participaçáo política off-line. O contexto brasileiro ainda carece de estudos na área do comportamento político que versem sobre os aspectos e relaçóes entre participação online e juventude. Como mostrado anteriormente a juventude é o grupo etário que mais utiliza a internet e os dados da pesquisa Democracia, mídia e capital social: um estudo comparativo de socialização politica dos jovens do Sul do Brasil, mostram que 56,1\% dos jovens entrevistados em Curitiba, 55,7\% em Florianópolis e 59,1\% em Porto Alegre acreditam que as redes sociais podem ser um local de participação política. Torna-se assim imperativa a necessidade pensar como as mídias digitais tem gerado uma participação política online entre os jovens, bem como, a relação com as modalidades presenciais de ação, sendo que este artigo se insere na busca de começar a suprir esta lacuna. Portanto, pautados na pesquisa supracitada passamos a analisar a participação política online e off-line do jovens estudantes das capitais da Regiáo Sul do Brasil. 


\section{Os condicionantes da participação dos jovens nas capitais do sul do Brasil}

\section{Questões metodológicas e hipóteses}

O presente artigo utiliza os dados da pesquisa intitulada Democracia, midia e capital social: um estudo comparativo de socialização política dos jovens do Sul do Brasil foi realizada nas três capitais da região Sul, em 2015, em Porto Alegre (RS), e em 2016, Curitiba (PR) e Florianópolis (SC), com alunos do ensino médio de escolas públicas $(64,5 \%)$ e privadas $(35,5 \%)$. Ao todo, foram coletados 2.035 questionários, sendo 690 de Porto Alegre, 571 para Florianópolis e 774 para Curitiba, com porcentagens semelhantes para cada ano do ensino médio (aproximadamente 33\% para cada uma das séries). O questionário era composto por 69 questóes que abordavam temas relacionados à política, mídias sociais e internet, e também, referentes ao ambiente escolar.

Tendo como plano de fundo as questôes teóricas abordadas até o presente momento sobre as relaçóes entre a participação políticas nos ambientes online e offline, bem como, os aspectos caracterizadores das atividades política juvenil, este trabalho parte das seguintes hipóteses: (a) os jovens tendem a ser mais ativos nas modalidades de protesto e nos ambientes digitais, por conta da resistência às instituiçôes características desta fase da vida, bem como em razão das suas habilidades com meio técnico; (b) assim como acontece no contexto nacional geral, os jovens que apresentam um maior sentimento de ineficácia política são mais ativos online; (c) a participação da juventude, assim como da sociedade em geral, apresenta uma tendência convergente entre as modalidades, contenciosas e institucionais, e entre os ambientes online e off-line; (d) o ambiente familiar tem influência direta na participação política dos jovens através do processo de socialização política.

Para tanto, selecionamos dentre as questôes disponíveis no questionário aquelas que se relacionam com atitudes políticas ${ }^{2}$ e participação política. No primeiro bloco temos interesse por politica, ciclo social que conversa sobre política, sentimento pelo país e pela politica, e, posicionamento ideológico. Além dessas, também, utilizamos variáveis que chamaremos de indice de desafeição com a política (IDP) e indice de ineficácia política (IIP). No segundo bloco, taxas e engajamento participativo em modalidades online e off-line (Tabela 1).

\footnotetext{
${ }^{2}$ Vide Apêndice Metodológico, para verificar o formato original e a recodificação da cada variável.
} 
Bloco 1 - Sobre os índices, pautados no objetivo de verificar mais estritamente a relaçáo dos jovens com a política, para além da ideia de avaliação positiva ou negativa, já mensuráveis nas questôes sobre os sentimentos, optamos pela construção de variáveis que conseguissem captar relaçóes mais profundas dos jovens com questôes políticas. Tanto a desafeição quanto a ineficácia dizem respeito à concepçôes mais subjetivas sobre o mundo político, tanto a ideia sobre política quanto sobre os políticos. O primeiro índice, indice de desafeição com a política (IDP), é resultante de um conjunto de afirmativas com temas relacionados à política, como corrupção e a opiniáo sobre o comportamento dos políticos, cujo enunciado dizia "Atualmente se fala muito do que está acontecendo no país. Qual a sua opiniâo sobre as seguintes afirmaçôes ${ }^{3 "}$, e demandava respostas entre concordo e discordo. O segundo, indice de ineficácia política (IIP) ${ }^{4}$, diz respeito às afirmativas sobre eficácia política individual e familiar, tendo o mesmo padrão de resposta da anterior.

Com a possibilidade de agrupamento dos conjuntos de questôes, criamos os dois índices sendo a escala das duas medidas com direção do menos desafeto e menos ineficaz para o mais desafeto e mais ineficaz. Dessa forma, o ponto mais alto para o indice de desafeição com a politica (IDP) é aquele jovem que mais desacredita na política, e para $o$ indice de ineficácia politica (IIP), o mais "ineficaz" é o que menos acredita na eficácia política individual e familiar. $\mathrm{O}$ indice de desafeição com a política (IDP) a escala vai de 0 a 6 e o indice de ineficácia política (IIP) vai de 0 a 8 pontos. Optamos por essa direção já que gostaríamos de mensurar a negação, ou seja, a desafeição com a política e a ineficácia política.

$\mathrm{Na}$ dimensão das atitudes políticas temos que em relação ao interesse por política, $60 \%$ dos estudantes dizem ter pouco interesse, contudo, há destaque para os $21,8 \%$ que possuem muito interesse. Este número é expressivo uma vez que se demonstra como o segundo maior percentual de respostas, o que explicita que os jovens das capitais são pouco interessados ou muito interessados, sendo minoritários os de posiçôes intermediárias. O principal ciclo social de conversa sobre assuntos

\footnotetext{
${ }^{3}$ Sete (7) eram as afirmaçóes contidas na bateria. Para criação do IDP utilizamos os itens: 25.1 Todos os políticos são corruptos; 25.2 Os políticos prometem, depois não cumprem; 25.3 Políticos são todos iguais.

${ }^{4}$ Para o IIP, foram agrupados os itens: 25.4 Náo gosto de discussóes ou assuntos políticos, porque ninguém se entende e prefiro não me incomodar; 25.5 Pessoas como as de minha família não têm nenhuma influência nas açóes do governo; 25.6 Náo adianta participar da política, pois nunca muda nada; 25.7 Assuntos políticos são muito complicados para mim, por isso não me interessam
} 
políticos é com os pais (23,5\% frequentemente e 40,9\% às vezes), e raramente $(30,9 \%)$ ou nunca $(21,3 \%)$ conversam com os contatos das redes sociais e os colegas de escola, isto pode ser um indicativo de quem são os referencias quando se trata de questôes políticas, o que evidencia o papel da família no processo de socialização política desses jovens.

Quando demandados sobre sentimentos em relação à política, tanto sentimentos positivos quanto negativos tiveram a mesma porcentagem de 35\%, apesar que $17 \%$ náo souberam responder como se sentem, enquanto que para os sentimentos em relaçáo ao país $96 \%$ possuem sentimentos negativos. Por um panorama geral, esses últimos dados podem ser interpretados da seguinte forma: por mais que haja um consenso sobre a sensação negativa que a atual situaçáo do país sugere, a avaliação negativa do país não é de toda ocasionada pela avaliação negativa da política.

Para os índices, em média, ambas as questôes apresentam valores semelhantes no ponto 3. Para o primeiro, IDP (0-6), esse valor representa o ponto intermediário, em contrapartida, para a questão de ineficácia, IIP (0-8), seria o ponto mais à esquerda tendendo a ser menos desafeto. Isso quer dizer que os estudantes não se sentem táo ineficazes politicamente, mas possuem sensação intermediária sobre seu desafeto pela política. Uma observaçáo importante, na escala de 0 a 10 sobre o posicionamento ideológico $56 \%$ dos estudantes não souberam se posicionar ou não quiseram responder. Para aqueles que responderam, a média encontra-se no ponto 5, importante observar que a distribuição nos pontos perto dos extremos é alta tanto a esquerda quando a direita.

Assim, os estudantes são pouco interessados em política em sua grande maioria, mas com um número expressivo daqueles que são muito interessados, gerando uma ambiguidade, que acaba se revelando nas demais características. Ao mesmo tempo a maioria não apresenta sentimentos negativos sobre a política, isto não ocorre em relação à situaçáo atual do país. $\mathrm{O}$ equilíbrio entre sentimentos negativos e positivos sobre a política pode ser refletido na posição intermediaria na escala de desafeto dos estudantes, e também, simultaneamente, se sentem mais eficazes politicamente. Contudo, o resultado do posicionamento ideológico, demonstra que os estudantes não sabem ou não querem se posicionar, e para aqueles que o fazem a tendência é ser centro, porém, os que não estão ao centro se posicionam nas extremidades. 
Bloco 2 - A partir disso, sobre o engajamento políticos dos jovens na Região Sul, a tabela abaixo (Tabela 1) apresenta as taxas individuais de participação política nas modalidades off-line e online.

De modo geral, os níveis de participação são baixos entre a juventude pesquisada, com patamares semelhantes ao conjunto da populaçáo brasileira. Destacamos aqui alguns dados que se distinguem daqueles descritos por Ribeiro e Borba $(2015)^{5}$, por exemplo, em especial aos que dizem respeito à participação em "atividades religiosas" em que $57,1 \%$ dos jovens dizem não participar, em oposição ao pertencimento e participação da população em geral nas igrejas cujas taxas chegam a 51,6\%. Do mesmo modo, enquanto $54,6 \%$ dos jovens da regiáo sul afirmam náo participar de abaixo-assinados, índice parecido da populaçáo geral (55,5\%), 35,7\% afirmam já terem feito parte deste tipo de atividade. Por fim, enquanto $58 \%$ da população brasileira tende a afirmar que "já fez ou poderia fazer" parte de manifestaçôes ou protestos, $58,7 \%$ da juventude do Sul diz que "não participa" desta modalidade. Ao passo que, em que pese, por exemplo, as manifestações de junho de 2013 terem sido marcadas pela forte presença de jovens mobilizados pela internet, ainda que os jovens das três capitais aqui analisadas reconhecerem em sua maioria que tais manifestaçóes foram importantes (em média $80 \%$ responderam ter sido importante as manifestaçôes), mais de $80 \%$ deles afirmaram que não compareceram àquele ciclo de protestos.

\footnotetext{
${ }^{5}$ Os dados utilizados pelos autores dizem respeito à World Values Survey de 2006.
} 
204 | Renata A. de Oliveira, Carla S. Ayres, Jaqueline Resmini Hansen e Julian Borba

Tabela1 - Frequências de participação dos jovens nas capitais da Região Sul (2015-2106) (\%)

\begin{tabular}{|c|c|c|c|}
\hline Modalidade & Participo & Já Participei & Náo Participo \\
\hline \multicolumn{4}{|c|}{ OFF-LINE } \\
\hline Atividades Religiosas & 20,8 & 22,1 & 57,1 \\
\hline Manifestaçóes, protestos, passeatas & 11,6 & 29,7 & 58,7 \\
\hline Abaixo Assinados & 9,7 & 35,7 & 54,6 \\
\hline Atividades no seu bairro & 9,2 & 26,4 & 64,4 \\
\hline Movimentos Sociais & 8,7 & 21,5 & 69,8 \\
\hline ONGs & 4,2 & 11 & 84,7 \\
\hline Associaçóes Comunitárias & 3,8 & 16,5 & 79,6 \\
\hline Ocupaçôes de terrenos ou prédios públicos & 1,6 & 3,2 & 95,2 \\
\hline Partidos Políticos & 1 & 1,2 & 97,8 \\
\hline Reuniōes Políticas & 0,9 & 5,1 & 94 \\
\hline Comícios Políticos & 0,8 & 3,3 & 95,8 \\
\hline Orçamento Participativo & 0,8 & 2,8 & 95,4 \\
\hline \multicolumn{4}{|c|}{ ONLINE } \\
\hline Abaixo assinado via internet & 10,6 & 24,6 & 64,8 \\
\hline Twittaços & 3,9 & 11,6 & 84,6 \\
\hline Boicotes via internet & 1,7 & 4,7 & 93,6 \\
\hline
\end{tabular}

A disposição das modalidades está por ordem decrescente de acordo com a resposta "participo".

$\mathrm{N}=1900$

Fonte: NUPESAL, 2015 e 2016.

Com base nas discussóes teóricas apresentadas acima quanto aos principais achados que vinculam de certa forma o perfil do ativismo online ao off-line, e ainda diante deste último dado, cabe-nos, entáo, investigarmos quais são as dimensóes da participação entre os jovens dos estados do Paraná, Santa Catarina e Rio Grande do Sul, bem como quais seus determinantes. Primeiramente, criamos índices de participação para cada modalidade através da análise fatorial, conforme tabela 1 do apêndice metodológico.

A pesquisa contemplava duas dimensóes de participação política, a online e off-line, com modalidades convencionais e não-convencionais. Sobre as modalidade off-line, por apresentar diferentes categorias, procuramos agrupá-las para criação de uma medida de participaçáo off-line. Através da análise fatorial, verificamos a impossibilidade da junção em um único fator, e assim, obtivemos 3 fatores que resultaram nas seguintes modalidades: 1) protestos; 2) eleitoral; 3) religiosa e comunitária. Ressalta-se que ONGs e OPs não foram inseridas em nenhuma destas categorias uma vez que não se agrupavam, conforme o teste alpha presente na tabela 1 do apêndice metodológico. 
Sendo assim, a modalidade de protestos inclui: abaixo-assinados; manifestaçóes, protestos ou passeatas; ocupaçôes de terrenos ou prédios públicos; movimentos sociais e atividades no bairro, mesclam modalidades convencionais e náo convencionais. A modalidade eleitoral é composta por participação em partidos políticos, reunióes políticas e comícios políticos, sendo caracterizado pelas modalidades mais convencionais. Por fim, a modalidade religiosa e comunitária para associaçôes comunitárias e atividades religiosas. Para a modalidade online através da fatorial, conseguimos agrupar, boicotes, twittaços e abaixo-assinados, em uma única categoria. Dessa forma, temos dois grupos de participação política, um com modalidades off-line, dividido em 3 categorias, e outro com as modalidades online.

Segundo os dados dos gráficos abaixo (Gráficos 1, 2, 3 e 4), em todas as modalidades a participação é baixa, tendo como maior frequência a não participação. A modalidade Eleitoral (Gráfico 2) é a que possui menor participação com cerca de $92 \%$ dos jovens náo participam de alguma das modalidades. Na Religiosa $e$ Comunitária (Gráfico 3), apesar dos jovens afirmarem não participarem dessa modalidade, aqueles que o fazem estáo concentrados em uma das atividades. Somente na modalidade de Protesto (Gráfico 1) que há uma maior participação, tendo 50,6\% participando de 1 a 3 atividades. Para a modalidade Online (Gráfico 4), a tendência também é baixa $(58,2 \%$ não participam), com $29 \%$ dos estudantes participando de apenas uma categoria, $9,1 \%$ de $2,8 \%$ das três modalidades.

Gráfico 1 - Modalidade protestos

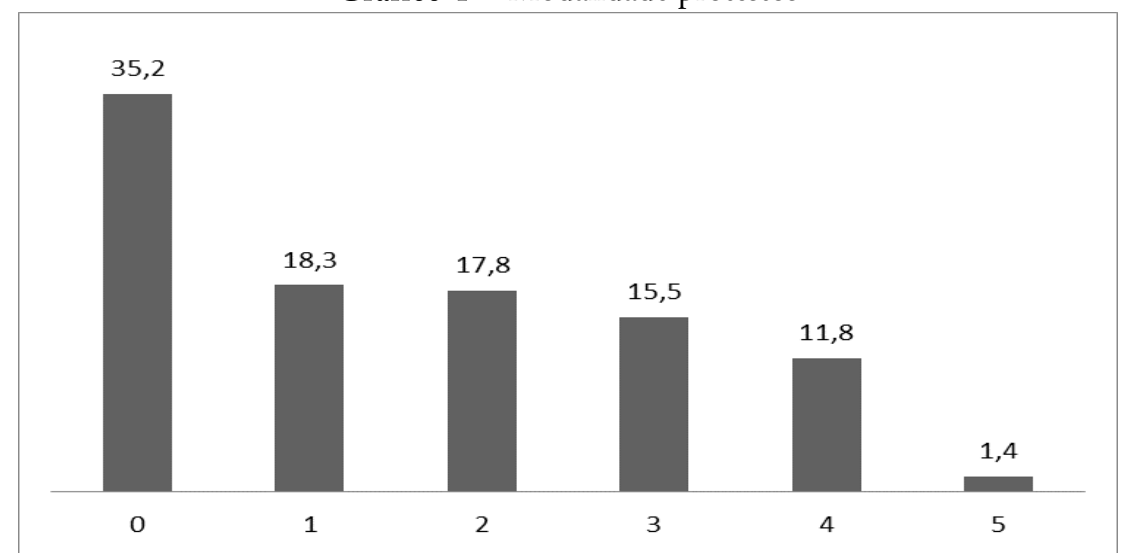

Fonte: NUPESAL, 2015 e 2016. 
206 | Renata A. de Oliveira, Carla S. Ayres, Jaqueline Resmini Hansen e Julian Borba

Gráfico 2 - Modalidade Eleitoral

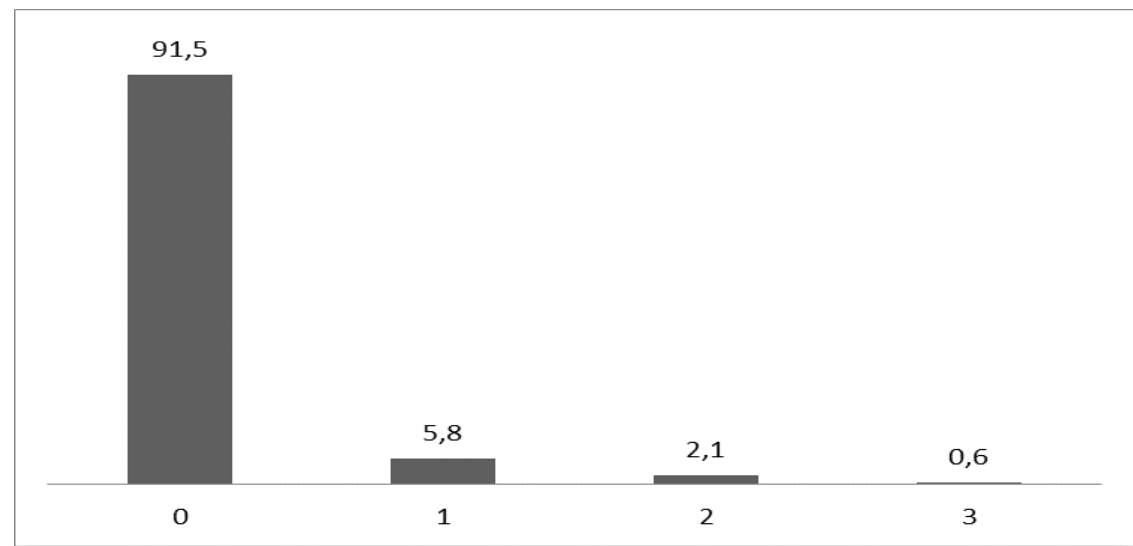

Fonte: NUPESAL, 2015 e 2016.

Gráfico 3 - Modalidade Religiosa e Comunitária

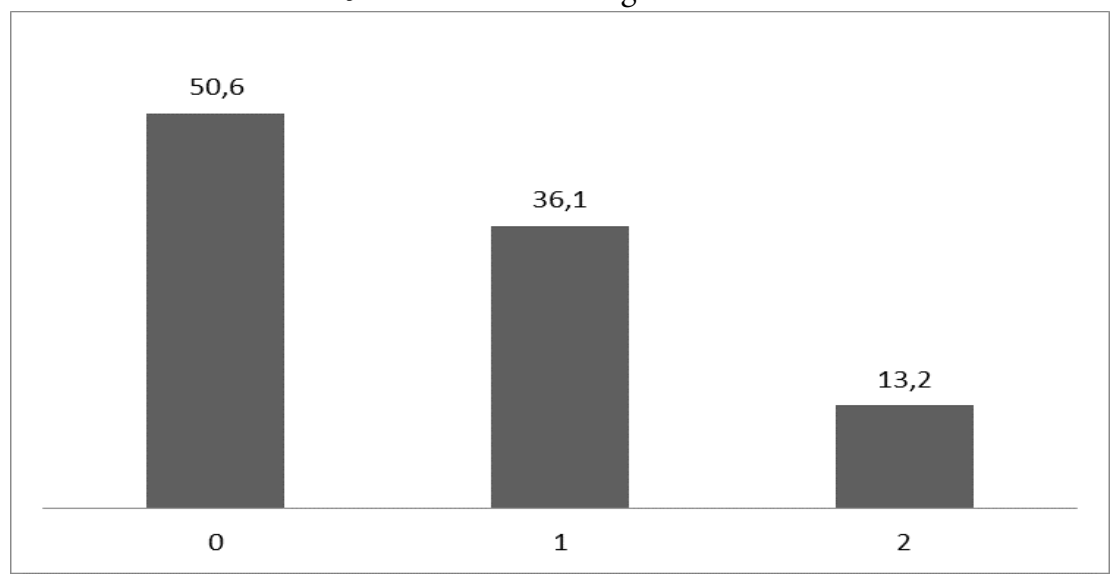

Fonte: NUPESAL, 2015 e 2016. 


\section{Gráfico 4 - Modalidade Online}

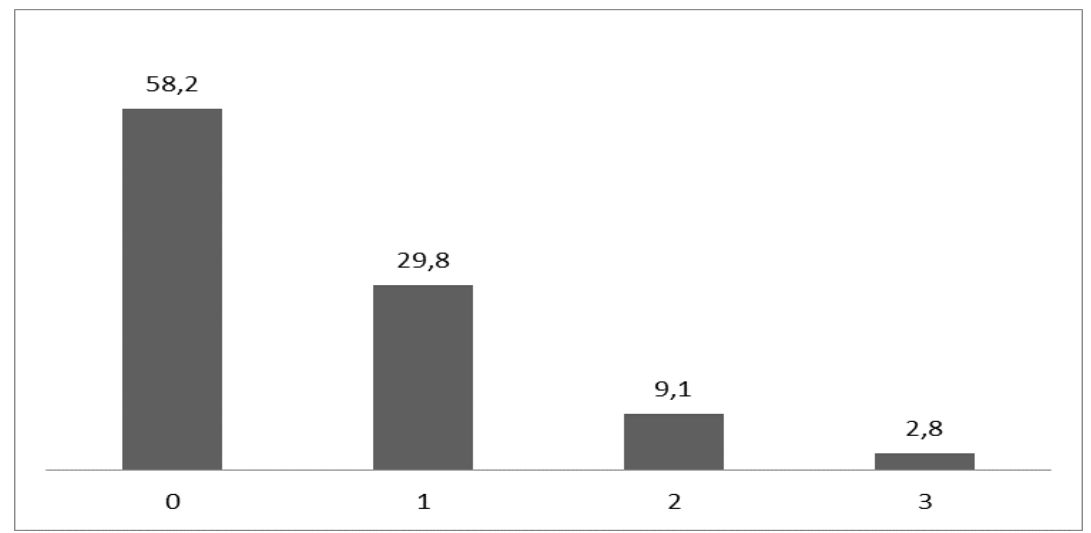

Fonte: NUPESAL, 2015 e 2016.

Conforme apresentaremos na seção abaixo, para cada uma das modalidades apresentadas acima, desenvolvemos um modelo de regressão para identificar os

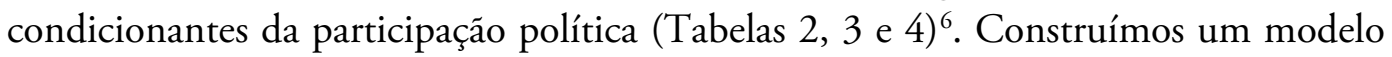
geral que une dados das três capitais, e, também, foram feitos modelos para cada uma das cidades, o que possibilita a comparação dos preditores em contextos diferentes. Para tanto, utilizamos como variáveis de controle, as sócio demográficas: idade, sexo, escolaridade dos pais e faixa de renda ${ }^{7}$. Também, acrescentamos variáveis políticas: interesse por política, as modalidades de participaçáo (off-line e online), os índices de desafeição pela política (IDP) e sobre ineficácia política (IIP), sentimento pelo país e pela política ${ }^{8}$.

\section{Os determinantes da participação}

Antes de passarmos propriamente para as discussóes dos modelos construídos, vale destacar rapidamente o perfil dos estudantes, cuja maioria é do sexo masculino $(51,4 \%)$ a idade varia de 13 a 26 anos, concentrando a maior parte entre 15 e 17 anos. Mais da metade dos estudantes moram com pai e mãe, e $24 \%$ moram apenas com a mãe. Em termos de escolaridade dos pais, 33\% possuem mães com ensino superior completo, $24 \%$ ensino médio completo e $14 \%$ ensino fundamental incompleto, e para os pais a tendência é a mesma, tendo proporção semelhante entre

\footnotetext{
${ }^{6}$ Vide Apêndice Metodológico, para verificar a recodificação das variáveis.

${ }^{7}$ Não foram acrescentadas as variáveis etnia e religião, pois eram questóes aberta e de livre escrita.

${ }^{8}$ Não utilizamos a variável posicionamento ideológico, pois a maioria dos estudantes não respondeu ou não soube responder, então o efeito não seria adequado.
} 
os níveis de educação. A porcentagem dos estudantes que não trabalham é de $65 \%$, sendo que $22 \%$ trabalham atualmente e $12 \%$ já trabalharam. Um dado de destaque é que em relaçáo à renda familiar, 30\% dos estudantes náo souberam responder, e daqueles que o fizeram, a faixa de renda é de 3 salários mínimos ou mais, sendo que os com maior renda está em Porto Alegre. De modo individual, as características dos estudantes de cada capital não apresentam variaçôes sociodemográficas relevantes.

Tabela 2 - Condicionantes das modalidades de participação- Protestos

\begin{tabular}{|c|c|c|c|c|}
\hline & Geral & Porto Alegre & Florianópolis & Curitiba \\
\hline \multicolumn{5}{|l|}{ Idade } \\
\hline Sexo & & & $\begin{array}{c}0,266 \\
(0,041) \\
\end{array}$ & \\
\hline Escolaridade Mãe & $\begin{array}{c}0,061 \\
(0,015) \\
\end{array}$ & & $\begin{array}{c}0,153 \\
(0,001)\end{array}$ & \\
\hline Escolaridade Pai & & & $\begin{array}{l}-0,109 \\
(0,013)\end{array}$ & \\
\hline \multicolumn{5}{|l|}{ Faixa de Renda } \\
\hline Interesse por política & $\begin{array}{c}0,169 \\
(0,015) \\
\end{array}$ & & $\begin{array}{c}0,297 \\
(0,018)\end{array}$ & \\
\hline Modalidade Eleitoral & $\begin{array}{c}0,327 \\
(0,000)\end{array}$ & $\begin{array}{c}0,267 \\
(0,031)\end{array}$ & & $\begin{array}{c}0,420 \\
(0,008)\end{array}$ \\
\hline $\begin{array}{lll}\text { Modalidade } & \text { Religiosa } \\
\text { Comunitária } & & \\
\end{array}$ & $\begin{array}{c}0,453 \\
(0,000)\end{array}$ & $\begin{array}{c}0,419 \\
(0,000)\end{array}$ & $\begin{array}{c}0,487 \\
(0,000)\end{array}$ & $\begin{array}{c}0,518 \\
(0,000)\end{array}$ \\
\hline Modalidade Online & $\begin{array}{c}0,751 \\
(0,000)\end{array}$ & $\begin{array}{c}0,860 \\
(0,000)\end{array}$ & $\begin{array}{c}0,751 \\
(0,000)\end{array}$ & $\begin{array}{c}0,640 \\
(0,000)\end{array}$ \\
\hline \multicolumn{5}{|l|}{ Desafeição Política (IDP) } \\
\hline Ineficácia Política (IIP) & $\begin{array}{l}-0,095 \\
(0,000) \\
\end{array}$ & & $\begin{array}{l}-0,102 \\
(0,004) \\
\end{array}$ & $\begin{array}{l}-0,099 \\
(0,002) \\
\end{array}$ \\
\hline \multicolumn{5}{|l|}{ Sentimento pelo País } \\
\hline \multicolumn{5}{|l|}{ Sentimento pela Política } \\
\hline $\mathrm{R}^{2}$ & 0,397 & 0,387 & 0,420 & 0,430 \\
\hline
\end{tabular}

Fonte: NUPESAL, 2015 e 2016.

No modelo 1 (Tabela 2), de modo geral, verificamos que os condicionantes da participação na modalidade de protestos em termos de preditores sociodemográficos, apenas a escolaridade da mãe é significante estatisticamente, o que indica para um impacto do ambiente familiar nas açóes de protesto dos jovens, e um argumento a favor da hipótese da socialização política. Em termos de atitudes foram significativas as variáveis de o interesse por política e Índice de Ineficácia Politica (IIP), 
no sentido negativo, ou seja, quanto menos o estudante se sente ineficaz politicamente maiores a chances de participar na modalidade de protestos, contrariando nossa hipótese de que os jovens menos eficientes fossem mais ativos. Por fim, a participação eleitoral, religiosa-comunitária e online também foram significativas indicando que a juventude segue a tendência nacional de combinar diferentes modalidades de ação política (RIBEIRO e BORBA, 2015) bem como, integrar os espaços online e off-line (HANSEN, 2016), fortalecendo a hipótese da convergência. Além disso, os dados também mostram que no contexto brasileiro, assim como no internacional, as modalidades de protesto tendem a ser fortalecidas pela participaçáo online (NORRIS e CURTICE, 2006; OSER, HOOGHE, MAREN, 2013; VALENZUELA, 2014).

Em termos de análise individual, a cidade de Florianópolis é a que mais chama a atenção, já que apresenta mais variáveis significantes, tendo um modelo que explica $42 \%$ da variável dependente. Exceto pela modalidade eleitoral, a participaçáo na modalidade de protestos em Florianópolis segue os parâmetros do modelo geral e das demais cidades, até com intensidades parecidas, além disso, também, tende a aumentar as chances de participação nessa modalidade quando se é mulher. É importante observar esse último dado já que se distingue da maioria das pesquisas sobre participação política nas quais os resultados apontam que os homens são os maiores participantes. Apesar de não ser um resultado conclusivo, ele expressa que na cidade de Florianópolis as jovens estão interagindo mais no mundo da política e através de repertórios de contestação. Isto pode ser indício de uma quebra de paradigmas entre a relação mulheres e política através dessa geração mais nova, as quais estão confrontando a ideia que nega o ambiente político das mulheres, e além disso, as formas contestatórias que geralmente são modalidades mais recentes de participação tem se demonstrado como novos caminhos abrindo espaços para essas jovens atuarem politicamente, não à toa o protagonismo organizativo das jovens mulheres em Florianópolis tem se expressado nos últimos anos em experiências como a Marcha das Vadias, a própria condução do Movimento Passe Livre local, a condução do OcupaMinc, na organização de diferentes coletivos feministas locais.

Também chama a atenção, em Florianópolis, o fato da baixa escolaridade do pai combinada com a maior escolaridade da mãe ter um efeito positivo no engajamento em protesto. Como discutimos anteriormente, a escolaridade é um recurso central para o engajamento político entre brasileiros, e, portanto, como os mais educados são os mais ativos, o maior nível educacional dos pais pode estar 
210 | Renata A. de Oliveira, Carla S. Ayres, Jaqueline Resmini Hansen e Julian Borba

relacionado a um ambiente de socializaçáo política mais engajado, e ter um efeito direto sobre a participaçáo dos filhos. Quando os dados de gerais mostram que a escolaridade da máe está relacionada com o engajamento em protesto, e os de Florianópolis mostram o engajamento dos filhos é condicionado pela a maior escolaridade da mãe e menor do pai, eles evidenciam as características patriarcais da sociedade em que as mulheres, mesmo inseridas no mercado de trabalho, ainda possuem o maior poder simbólico sobre os filhos. Assim, ao mesmo tempo que o resultado fortalece o argumento acerca do papel da família na socializaçáo política, ele expóe uma fragilidade na coesão interna do argumento da escolaridade, uma vez que o parece que aqueles jovens que o pai é dotado de menos recursos educacionais são os que procuram as formas contenciosas para se expressar.

Tabela 3 - Condicionantes das modalidades de participação- Eleitoral

\begin{tabular}{|c|c|c|c|c|}
\hline & Geral & Porto Alegre & Florianópolis & Curitiba \\
\hline Idade & $\begin{array}{c}0,018 \\
(0,001)\end{array}$ & $\begin{array}{c}, 050 \\
(0,017) \\
\end{array}$ & & $\begin{array}{c}0,012 \\
(0,013) \\
\end{array}$ \\
\hline \multicolumn{5}{|l|}{ Sexo } \\
\hline Escolaridade Mãe & & & $\begin{array}{c}0,035 \\
(0,016)\end{array}$ & \\
\hline \multicolumn{5}{|l|}{ Escolaridade Pai } \\
\hline \multicolumn{5}{|l|}{ Faixa de Renda } \\
\hline Interesse por política & $\begin{array}{c}0,057 \\
(0,021)\end{array}$ & $\begin{array}{c}0,118 \\
(0,023)\end{array}$ & $\begin{array}{c}0,079 \\
(0,048)\end{array}$ & \\
\hline Modalidade Protestos & $\begin{array}{c}0,042 \\
(0,000)\end{array}$ & $\begin{array}{c}0,045 \\
(0,031)\end{array}$ & & $\begin{array}{c}0,043 \\
(0,008)\end{array}$ \\
\hline $\begin{array}{l}\text { Modalidade Religiosa e } \\
\text { Comunitária }\end{array}$ & $\begin{array}{c}0,086 \\
(0,000)\end{array}$ & $\begin{array}{c}0,146 \\
(0,000)\end{array}$ & $\begin{array}{c}0,095 \\
(0,002)\end{array}$ & $\begin{array}{c}0,054 \\
(0,051)\end{array}$ \\
\hline \multicolumn{5}{|l|}{ Modalidade Online } \\
\hline Desafeição política (IDP) & $\begin{array}{l}-0,022 \\
(0,013)\end{array}$ & & & \\
\hline Ineficácia Política (IIP) & & $\begin{array}{c}0,029 \\
(0,050)\end{array}$ & & \\
\hline Sentimento pelo País & $\begin{array}{l}0,306 \\
(0,000)\end{array}$ & $\begin{array}{c}0,472 \\
(0,000)\end{array}$ & & $\begin{array}{c}0,268 \\
(0,010)\end{array}$ \\
\hline \multicolumn{5}{|l|}{ Sentimento pela Política } \\
\hline $\mathrm{R}^{2}$ & 0,118 & 0,167 & 0,137 & 0,138 \\
\hline
\end{tabular}

Fonte: NUPESAL, 2015 e 2016. 
$\mathrm{Na}$ modalidade de participaçấo eleitoral (modelo 2, Tabela 3), a idade foi significativa, indicando que os estudantes mais velhos são mais propícios ao engajamento eleitoral. Esse resultado está em consonância com os achados de Okado e Ribeiro, (2015) que mostram que as atividades ligadas ao processo eleitoral são mais comumente executadas por adultos. Além disso, este dado deve ser interpretado levando em consideração duas características que envolvem a atividade eleitoral no Brasil: 1) que o nosso universo congrega estudantes de 13 a 26, e que; 2) o voto no Brasil é facultativo a partir dos 16 anos, porém obrigatório a partir dos 18 anos; neste cenário se justifica o engajamento eleitoral compulsório aos mais velhos.

Novamente, a participação em outras modalidades, protesto e religiosacomunitária, indicam para a convergência das modalidades convencionais e contestatórias, embora neste caso não ocorra integração com o ambiente online. $\mathrm{O}$ resultado indica para duas frentes em relação a hipótese da convergência: ela se fortalece em decorrência do efeito nas modalidades off-line, porém, apresenta uma ruptura com o mundo online, indicando que ele dialoga de maneira distinta com as diferentes modalidades. A participação eleitoral é favorecida entre aqueles que são mais interessados nos assuntos políticos, que sentem menos desafetos pela política e os que possuem sentimentos positivos pelo país, estes resultados, mostram para uma fragilidade do argumento hipotético de que a participação dos mais jovens estaria atrelada a um maior desafeto e ineficácia política. A cidade que mais segue este perfil é Porto Alegre. A diferença está em que, para a capital gaúcha, o desafeto pela política não é significativo, mas a ineficácia política tem efeito, sendo que os que tendem a se sentir mais ineficazes são os que procuram participar de alguma das modalidades dessa categoria, e deste modo, ajuda a fortalecer a hipótese da relação entre ineficiência política e engajamento juvenil. Já Florianópolis e Curitiba divergem um pouco do modelo geral, sendo a primeira, a que possui menos variáveis que afetam a participação na modalidade eleitoral e a segunda, não apresenta significância para interesse por política e índice de desafeição política. 
212 Renata A. de Oliveira, Carla S. Ayres, Jaqueline Resmini Hansen e Julian Borba

Tabela 4 - Condicionantes das modalidades de participação- Religiosa e Comunitária

\begin{tabular}{|c|c|c|c|c|}
\hline & Geral & Porto Alegre & Florianópolis & Curitiba \\
\hline \multicolumn{5}{|l|}{ Idade } \\
\hline \multicolumn{5}{|l|}{ Sexo } \\
\hline \multicolumn{5}{|l|}{ Escolaridade Mãe } \\
\hline Escolaridade Pai & & $\begin{array}{l}-0,056 \\
(0,032)\end{array}$ & & \\
\hline Faixa de Renda & $\begin{array}{l}-0,054 \\
(0,004) \\
\end{array}$ & $\begin{array}{c}-0,071 \\
(0,034)\end{array}$ & & \\
\hline \multicolumn{5}{|l|}{ Interesse por política } \\
\hline Modalidade Protestos & $\begin{array}{c}0,151 \\
(0,000) \\
\end{array}$ & $\begin{array}{c}0,123 \\
(0,000)\end{array}$ & $\begin{array}{c}0,161 \\
(0,000)\end{array}$ & $\begin{array}{c}0,174 \\
(0,000)\end{array}$ \\
\hline Modalidade Eleitoral & $\begin{array}{c}0,226 \\
(0,000) \\
\end{array}$ & $\begin{array}{c}0,251 \\
(0,000)\end{array}$ & $\begin{array}{c}0,310 \\
(0,002)\end{array}$ & $\begin{array}{c}0,180 \\
(0,051)\end{array}$ \\
\hline \multicolumn{5}{|l|}{ Modalidade Online } \\
\hline \multicolumn{5}{|l|}{ Desafeição Política (IDP) } \\
\hline \multicolumn{5}{|l|}{ Ineficácia Política (IIP) } \\
\hline \multicolumn{5}{|l|}{ Sentimento pelo País } \\
\hline Sentimento pela Política & & & $\begin{array}{l}-0,002 \\
(0,041) \\
\end{array}$ & \\
\hline $\mathrm{R}^{2}$ & 0,158 & 0,174 & 0,178 & 0,213 \\
\hline
\end{tabular}

Fonte: NUPESAL, 2015 e 2016.

Quanto à participação religiosa e comunitária (modelo 3, Tabela 4), ela é mais intensa entre aqueles que possuem menor renda. Novamente a participaçáo nas modalidades de protesto e eleitoral se mostraram significativas, confirmando a convergência das modalidades de engajamento, bem como indicando, como já apontado por Verba, Scholzman e Brady (1995) que a dimensão cívica tem uma importância fundamental na vida pública. Este resultado, por um lado fortalece o argumento da convergência, mas assim como para participação eleitoral mostra uma ruptura com o mundo online, o qual se apresenta cada vez menos articulado com as modalidades institucionais. Isto, também, pode indicar que aqueles que tem menos renda são também os que tem menor acesso à internet, e portanto, existe entre eles uma tendência d que a interação comunitária seja mais efetiva do que a online. Em todas as cidades, a participação nas demais modalidades também apresenta efeitos significativos, e em Porto Alegre ainda há o acréscimo da escolaridade do pai, que sendo mais baixa tende a aumentar a participação, repetindo um efeito já comentado sobre a modalidade de protesto. E em Florianópolis, também, aparece como significante ter sentimentos negativos pela política. 
Tabela 5 - Condicionantes das modalidades de participação- Online

\begin{tabular}{|c|c|c|c|c|}
\hline & Geral & Porto Alegre & Florianópolis & Curitiba \\
\hline \multicolumn{5}{|l|}{ Idade } \\
\hline \multicolumn{5}{|l|}{ Sexo } \\
\hline \multicolumn{5}{|l|}{ Escolaridade Mãe } \\
\hline \multicolumn{5}{|l|}{ Escolaridade Pai } \\
\hline \multicolumn{5}{|l|}{ Faixa de Renda } \\
\hline Interesse por política & $\begin{array}{c}0,094 \\
(0,018)\end{array}$ & & & $\begin{array}{c}0,184 \\
(0,008)\end{array}$ \\
\hline Modalidade Protestos & $\begin{array}{c}0,224 \\
(0,000)\end{array}$ & $\begin{array}{c}0,272 \\
(0,000)\end{array}$ & $\begin{array}{c}0,214 \\
(0,000)\end{array}$ & $\begin{array}{c}0,243 \\
(0,000)\end{array}$ \\
\hline \multicolumn{5}{|l|}{ Modalidade Eleitoral } \\
\hline \multicolumn{5}{|l|}{$\begin{array}{l}\text { Modalidade Religiosa e } \\
\text { Comunitária }\end{array}$} \\
\hline \multicolumn{5}{|l|}{ Desafeição Política (IDP) } \\
\hline Ineficácia Política (IIP) & $\begin{array}{l}-0,022 \\
(0,053)\end{array}$ & $\begin{array}{l}-0,052 \\
(0,010)\end{array}$ & & \\
\hline \multicolumn{5}{|l|}{ Sentimento pelo País } \\
\hline Sentimento pela Política & $\begin{array}{l}-0,002 \\
(0,006)\end{array}$ & $\begin{array}{l}-0,002 \\
(0,034)\end{array}$ & $\begin{array}{l}-0,002 \\
(0,040)\end{array}$ & \\
\hline$\overline{\mathrm{R}^{2}}$ & 0,301 & 0,335 & 0,292 & 0,321 \\
\hline
\end{tabular}

Fonte: NUPESAL, 2015 e 2016.

Por fim, em relação à participação política online (modelo 4, Tabela 5), nenhum preditor sociodemográfico apresentou-se como significativo no modelo geral e nem para as cidades. Já os fatores associados à política, para o geral, tem-se que os mais interessados em política, os que possuem sentimentos negativos pela política e maior sentimento de eficácia política participam mais da esfera online, contrariando a hipótese de que o maior sentimento de ineficiência influenciaria positivamente o engajamento online, o que, também, vai na contramão dos achados para população brasileira em geral em que o sentimento de ineficácia afeta positivamente a participação online (HANSEN, 2016). Além disso, a participação em protestos aumenta as chances do ativismo online, favorecendo a hipótese da convergência e mostrando que na juventude brasileira as modalidades mais diretas - protesto e online - se favorecem mutuamente, a participação em protesto é a variável com maior força explicativa, o que fortalece, mesmo que minimamente, a hipótese de que os jovens preferem as modalidades de protesto e online. 
214 | Renata A. de Oliveira, Carla S. Ayres, Jaqueline Resmini Hansen e Julian Borba

É importante ressaltar que as modalidades institucionalizadas por não ajudarem a explicar a participação online entre os jovens, evidenciam uma fragilidade do argumento da convergência pela ausência de relação na participação juvenil entre o mundo online $\mathrm{e}$ as modalidades off-lines institucionalizadas. Um fato a ser observado é que nas cidades de Porto Alegre e Florianópolis, pela primeira vez, o interesse por política não é um condicionante para a participação online, ao mesmo tempo, para Florianópolis e Curitiba o sentimento de ineficácia política também não é significativo.

Nesse sentido, diante de todo o cenário apresentado, temos que a participação política dos jovens nas capitais do Sul do Brasil acompanha uma tendência nacional de participaçáo na maioria das modalidades, tanto online quanto off-line (convencionais e não-convencionais). O que podemos destacar é que nas modalidades de caráter mais contestatórias (Protestos e Online) há uma maior participação em ao menos uma das modalidades, e também, pelos nossos testes, elas se apresentam como preditores entre si, o que caracteriza uma ligação entre o mundo off-line e online. Enquanto o perfil das cidades, percebemos que há algumas diferenças, mas de modo geral, os condicionantes para os jovens são semelhantes mesmo com diferenças contextuais, destacando que poucos são os preditores sóciodemográficos, sendo os condicionantes mais forte e presentes os que possuem ligação direta com o mundo da política.

Portanto, a luz destes resultados e de nossas hipóteses podemos tecer alguns argumentos. A hipótese de que os jovens são mais ativos nas modalidades de protesto e no mundo online pode ser confirmada, através das frequências percentuais", entretanto, elas nos surpreendem a mostrar um percentual elevado também no ativismo comunitário, indicando que os jovens podem se preocupar mais com os problemas comunitários que são mais concretos e os atingem diariamente do que com os aspectos nacionais que são mais abstratos. $\mathrm{O}$ fortalecimento mútuo das modalidades de protesto e online também influência na confirmação da primeira hipótese.

No tocante a segunda hipótese, que trata do sentimento de ineficiência e de desafeição como condicionantes do ativismo juvenil apresentou resultados positivos apenas na participação eleitoral entre os jovens de Porto Alegre, eles foram os únicos

\footnotetext{
${ }^{9}$ Relembrando que eles afirmaram já ter participado: Abaixo assinado (35,7\%), Protesto (29,7\%), Atividades no bairro (26,4\%); Abaixo assinado online (24,6\%); Religiosa (22,1\%); Movimentos Sociais (21,5\%); Associação comunitária (16\%); Twittaços (11,6\%); ONGs (11\%). A participação eleitoral, ocupações e boicotes apresentam menos de $5 \%$ de participação.
} 
que o sentimento de ineficiência levou ao ativismo político. Nas outras modalidades, tanto no geral, quanto para as cidades, quando os Índices de Ineficácia Política e Desafeição Política foram significantes eles atuaram no sentido oposto do esperado, e, portanto, foram os sentimentos de eficiência e de afeição política que tiveram influência positiva no comportamento político eleitoral, de protesto e online. Para o ativismo comunitário e religioso estes índices não foram relevantes, indicando que este tipo de engajamento não está atrelado a este tipo de avaliaçóes subjetivas.

A hipótese da convergência, na qual está implícita a ideia de convergência entre as modalidades institucionais e contestatórias, bem como das dimensões online e off-line, apresentou resultados conflitantes. Se por um lado, as modalidades eleitorais, de protesto e comunitário se fortalecem e indicam que os indivíduos atuam em ambas as modalidades e confirmam a hipótese. Por outro lado, ela apresenta uma ruptura uma vez que a dimensão online só se relaciona com as modalidades de protesto, e assim, apesar da convergência ainda se fazer valer, existe a possibilidade de que indivíduos sejam ativos somente nessas modalidades contenciosas e a convergência com as modalidades institucionais fique enfraquecida.

Por fim, a última hipótese, relacionada ao processo de socialização política não pode ser confirmada nem rejeitada. Embora a baixa escolaridade do pai tenha se mostrado como um preditor para o ativismo de protesto em Florianópolis e do ativismo comunitário-religioso em Porto Alegre, o resultado indica para uma fragilidade do argumento, mas não é forte o suficiente para rejeitá-lo. Como o aumento da escolaridade da mãe só se mostrou significativo na modalidade de protesto, podemos argumentar que os dados mostram um papel restrito da socialização familiar no processo de ativismo juvenil, entretanto, os dados também não suficientes para afirmarmos a ausência de impacto familiar, sendo necessário pesquisas mais aprofundadas neste aspecto.

\section{Considerações finais}

Os resultados do nosso estudo permitem explorar alguns aspectos da participaçáo política dos jovens. Primeiramente, a centralidade do interesse por política, o que corrobora a tese de que as motivações individuais têm um papel fundamental no engajamento político. Segundo, apenas na modalidade eleitoral o ambiente familiar se mostrou relevante, indicando para um possível efeito direto sobre a participação, porém tais resultados não nos permitem avançar em conclusôes acerca do impacto da socializaçáo nos processos de participação destes jovens. 
216 | Renata A. de Oliveira, Carla S. Ayres, Jaqueline Resmini Hansen e Julian Borba

Um terceiro aspecto relevante é sobre a relação entre as diferentes modalidades de ação política e os ambientes em que elas ocorrem (online ou off-line). Os dados mostraram que as formas de participação off-line (comunitário-religiosa, eleitoral e de protesto) se fortalecem mutuamente, uma vez que se apresentam umas como preditoras das outras, e isso indica para uma convergência das modalidades de participação entre os jovens. Assim, podemos dizer que quando os cidadáos possuem uma atitude participativa convergente eles ativam tanto as modalidades institucionais quanto as contestatórias, entretanto, quando passamos para a participação online, esta é influenciada e influencia apenas as modalidades de protesto, de modo que podemos inferir que no contexto da juventude brasileira a integração entre online e off-line (DAHLGREEN, 2005) ocorre pelo fortalecimento das atividades contenciosas. Portanto, assim como apontaram Gibson e Cantijoch (2013), no contexto da juventude brasileira o ambiente online se apresenta como independente do off-line nas modalidades convencionais e cívicas participação, contudo, também existe uma integração entre as dimensões online e off-line via modalidades de protesto.

- Renata A. de Oliveira é Doutoranda no Programa de Pós Graduação em Sociologia Política da Universidade Federal de Santa Catarina (UFSC). E-mail: rehnata_andrade@hotmail.com.

- Carla S. Ayres é Doutoranda no Programa de Pós Graduação em Sociologia Política da UFSC. E-mail: carlazzl@hotmail.com.

- Jaqueline Resmini Hansen é Doutoranda no Programa de Pós Graduação em Ciência Política da Universidade Federal de Minhas Gerais (UFMG). E-mail: jaqueline.hansen@live.com.

- Julian Borba é Doutor em Ciência Política, pela Universidade Federal do Rio Grande do Sul. É Professor no Programa de Pós Graduação em Sociologia Politica da UFSC. E-mail: borbajulian@yahoo.com.br.

\section{Referências}

BARBER, Benjamin. Strong democracy: participatory politics for new age. California: University Of California Press. 20th anniversary edition, 2003. 
BEST, Samuel; KRUEGER, Brian. Analyzing the representativeness of internet political participation. Political Behavior, v. 27, n. 2, 2005. p. 183-216. Disponível em <http://www.jstor.org/stable/4500191>. Acesso em 15 jan. 2010.

BORBA, Julian; RIBEIRO, Ednaldo. Participação convencional e não convencional na América Latina. Revista Latino-Americana de Opinión Pública, v. 1, 2010. p. 53- 76.

BORBA, Julian; RIBEIRO, Ednaldo. Participação convencional e não convencional na América Latina. In: BAQUERO, Marcelo (org.). Cultura(s) Politica(s) e Democracia no Século XXII na América Latina. Porto Alegre: UFRGS, 2011, p. 95-118.

BRASIL. Presidência da República. Secretaria de Comunicação Social. Pesquisa brasileira de mídia 2015: hábitos de consumo de mídia pela população brasileira. - Brasília: Secom, 2014. Disponível em <http://www.secom.gov.br/atuacao/pesquisa/lista-de-pesquisas-quantitativasequalitativas-de-contratos-atuais/pesquisa-brasileira-de-midia-pbm-2015.pdf>. Acesso em 02 abr. 2015.

BRUNDIDGE, Jenifer; RICE, Ronald. Political engagement online: do the information rich get richer and like-minded more similar. In CHADWICK, Andrew; HOWARD, Philip. The Routledge Handbookof Internet Politics. New York, Routledge, 2009.

CASSAB, Clarice. Contribuição à construção das categorias jovem e juventude: uma introdução. Revista Locus, Juiz de Fora. v. 17, n.2, 2011. p. 145-159.

COMITE GESTOR DA INTERNET NO BRASIL - CGI. Pesquisa sobre o uso das tecnologias da informação e comunicação no Brasil [livro eletrônico]: TIC domicílios e empresas 2013 = Survey on the use of information and communication technologies in Brazil: ICT households and enterprises 2013. 2014. Disponível em $<$ http://www.cetic.br/publicacao/pesquisa-sobre-o-uso-das-tecnologias-de-informacaoecomunicacao-no-brasil-tic-domicilios-e-empresas-2013/>. Acesso em 17 set. 2015.

DAHLGREN, Peter. Internet, public spheres and political communication: dispersion and deliberation. Political Communication. n. 22, 2005. p. 147-162. Disponível em <http://courses.washington.edu/insc555/wordpress/wp-content/readings/Dahlgren_2005.pdf>. Acesso em 22 nov. 2015.

DALTON, Russel. J. The good citizen: How a younger generation is reshaping American politics. Washington: CQ Press, 2009.

DALTON, Russel J.; VAN SICKLE, Alix. The Resource, Structural, and Cultural Bases of Protest. Publicado por Center for the Study of Democracy CSD, University of California em 08/08/2005. Disponível em <https://escholarship.org/uc/item/3jx2b911>. Acesso em 24 jan. 2015.

FLANAGAN, Constance. A. Teenage Citizens: The Political Theories of the Young. New York: Harvard University Press, 2013.

FUKS, Mario. Efeitos diretos, indiretos e tardios: trajetórias da transmissão intergeracional da participação política. Lua Nova, São Paulo, v. 83, 2011. p. 145-178.

GIBSON, Rachel; CANTIJOCH, Marta. Conceptualizing and Measuring Participation in the Age of the Internet: Is Online Political Engagement Really Different to Offline? The Journal of Politics, v. 75, n. 3, 2013. p. 701-716.

HAFNER FINK, Mitja; OBLAK ČRNIČ, Tanja. Digital citizenship as multiple political participation? Predictors of digital political participation in Slovenia. Teorija in Praska. let. 51, 2014. 
p. 1284-1303. Disponível em <http://www.fdv.uni-lj.si/docs/defaultsource/tip/tip_06_2014_hafnerfink_idr.pdf?sfvrsn=2>. Acesso em 24 jan. 2015.

HANSEN, Jaqueline Resmini. Participação política no ciberespaço: condicionantes e relaçóes do engajamento online no Brasil. Anais do X Encontro da Associação Brasileira de Ciência Politica $(A B C P)$. Belo Horizonte, 2016. $\quad$ Disponível em <http://www.encontroabcp2016.cienciapolitica.org.br/resources/anais/5/1468870404_ARQUIVO_ Hansen,J.Participacaonociberespaco.pdf>. Acesso em 10 out. 2016.

HJAVARD, Stig. Midiatização: teorizando a mídia como agente de mudança social e cultural. Matrizes. $\quad$ v. $\quad 5, \quad$ n. 2, 2012. p. 53-91. Disponível em <http://www.revistas.univerciencia.org/index.php/MATRIZes/article/view/8139/7505>. Acesso em 17 set. 2015.

INGLEHART, Ronald; WELZEL, Christian. Modernization, cultural change, and democracy: The human development sequence. New York: Cambridge University Press. 2005.

ITU. Internacional Telecommunication Union. Mensuring the information society report 2014. Geneva Switzerland, 2014. ISBN 978- 92-61-15291-8. Disponível em <http://www.itu.int/en/ITUD/Statistics/Documents/publications/mis2014/MIS2014_without_Ann ex_4.pdf>. Acesso em 24 jan. 2015.

KINDER, Donald. Politics and the life cycle. Science, v. 312, n. 5782, 2006. p. 1905-1908.

KRISCHKE, Paulo. Perfil da juventude brasileira: questôes sobre cultura política e participação democrática. Interthesis, Florianópolis, v. 1, n. 2, 2004. p. 1-27.

LATINOBAROMETRO. Opinion Publica Latinoamericana. Disponível em $<$ http://www.latinobarometro.org/>.

LAPOP. Latin American Public Opinion Project. Disponível em $<$ http://www.vanderbilt.edu/lapop/>.

LIVINGSTONE, Sonia. Intenet Literacy: a negociação dos jovens com as novas oportunidades online. Matrizes. São Paulo, ano 4, n. 2, 2011. p. 11-42. Disponível em <http://www.redalyc.org/articulo.oa?id=143018637002>. Acesso em 17 set. 2015.

MARGETTS, Helen. The Internet and Democracy. In DUTTON, William. (org) The Oxford Handbook of Internet Studies. Oxford, UK: Oxford University Press, 2013.

MARTINO, Luis Mauro Sá. Teoria das Midias Digitais: linguagens, ambientes e redes. 2a edição. Petrópolis, RJ: Editora Vozes, 2015.

MESQUITA, Nuno Coimbra; CANTONI, Stefania. Participação Política On-line vs. Off-line no Brasil. In: MEQUITA, Nuno Coimbra. (org) Brasil: 25 anos de democracia: participação, sociedade civil e cultura política. Rio de Janeiro, Fundação Konrad Adenauer, 2016.

MEYROWITZ, Joshua. Images of media: hidden fermente - and harmony - in the field. Journal of Communication, v. 43, n. 3, 1993. p. 55-66.

MILBRATH, Lester. Political Participation. Chicago: RandMcNally, 1965.

MOSSBERGER, Karen. Toward digital citzenship: addressing inequality in the information age. In CHADWICK, Andrew. HOWARD, Philip. The Routledge Handbook of Internet Politics. New York, Routledge, 2009.

NORRIS, Pippa. Digital Divide: civic engagement, information poverty anda the internet worldwide. Cambridge: Cambridge University Press, 2001. Disponível em <http://www.hks.harvard.edu/fs/pnorris/Books/Digital\%20Divide.htm>. Acesso em 13 out. 2014. 
NORRIS, Pippa. Democratic Phoenix: Reinventing Political Activism. Cambridge: Cambridge University $\quad$ Press, $2002 . \quad$ Disponível em <https://sites.google.com/site/pippanorris3/publications/books/democratic-phoenix>. Acesso em 07 mai. 2014.

NORRIS, Pippa. Young people and political activism: From the Politics of Loyalties to the Politics of Choice? Report for the Council of Europe Symposium. 2003 Disponível em <http://www.pippanorris.com>. Acesso em 07 mai. 2014.

NORRIS, Pippa. The evolution of election campaigns: Eroding political engagement? Conference on Political Communications in the 21st. Century. 2004. Disponível em $<$ http://www.pippanorris.com>. Acesso em 07 mai. 2014.

NORRIS, Pippa; CURTICE, John. If you build a political web site, will they come? The internet and political activism in Britain. International Journal of Electronic Government Research, v. 2, n. 2, 2006. p. $1-21$ Disponível em <http://www.hks.harvard.edu/fs/pnorris/Articles/Articles\%20published\%20in\%20journals_filfi/IJE GR\%20Website\%20Norris\%20and\%20Curtice.pdf>. Acesso em 01 dez. 2014.

NUPESAL. Pesquisa Democracia, mídias e capital social: um Estudos comparativo de Socialização política dos jovens no Sul do Brasil (Porto Alegre, Curitiba e Florianópolis) 2015- 2016.

OKADO, Lucas Toshiaki Archangelo; RIBEIRO, Ednaldo Aparecido. Condiçáo juvenil e participação política no Prasil. Paraná Eleitoral: Revista Brasileira de Direito Eleitoral e Ciência Politica. Curitiba, v. 4, n. 1, 2015. p. 53-78. Disponível em <http://www.justicaeleitoral.jus.br/arquivos/tre-prparana-eleitoral-2015-volume-4revista-1-artigo-2-lucas-toshiaki>. Acesso em 07 mai. 2015.

OSER, Jenifer; HOOGHE, Marc; MARIEN, Sofie. Is Online Participation Distinct from Offline Participation? A Latent Class Analysis of Participation Types and Their Stratification. Political Research Quarterly, v. 66, n. 1, 2013. p. $91-101$.

PUTNAM, Robert. Bowling alone. New York: Simon \& Schuster, 2001.

RIBEIRO, Ednaldo. Valores pós-materialistas e cultura politica no Brasil. Maringá: Eduem, 2011.

RIBEIRO, Ednaldo; AYRES, Carla Simara. Democracia, participação e mudança geracional no Brasil. Século XXI.UFSM, Santa Maria, v. 1, n.2, p. 62-18, jul/dez., 2011.

RIBEIRO, Ednaldo; BORBA, Julian. Participação política na América Latina. Maringá: Eduem, 2015. SCHLEGEL, Rogério. Internauta brasileiro: perfil diferenciado, opiniōes indiferenciadas. Revista de Sociologia e Política, Curitiba, v. 17, n. 34, p. 137-157, out. 2009. Disponível em <http://www.scielo.br/scielo.php?pid=S0104-44782009000300011\&script=sci_arttext $>$. Acesso em 14 fev. 2014.

THEOCHARIS, Yannis. The Conceptualization of Digitally Networked Participation. Social Media + Society, 2015. p. 1-14.

VALENZUELA, Sebastian; ARRIGADA, Arturo; SCHERMAN, Andrés. The social media basis of Youth Protest Behavior: The Case of Chile. Journal of Communication, v. 62 (International Communication Association), 2012. p. 299-314.

VALENZUELA, Sebastian. Analisando o uso de redes sociais para o comportamento de protesto: o papel da informação, da expressão de opiniôes e do ativismo. Tradução Letícia Perani. Revista Compolitica, n. 4, v. 1, 2014. 
220 | Renata A. de Oliveira, Carla S. Ayres, Jaqueline Resmini Hansen e Julian Borba

VERBA, Sidney; SCHLOZMAN, Kay Lehman; BRADY, Henry. Voice and Equality: civic voluntarism in American politics. Cambridge, Mass.: Harvard University Press, 1995.

WVS. Word Values Survey. Disponível em <http://www.worldvaluessurvey.org/wvs.jsp>.

Texto recebido em 13 de dezembro de 2016. Aprovado em 15 de dezembro de 2016. 


\section{Anexo}

\section{Anexo Metodológico}

Variável: Interesse por Política

Questão 3. Você se interessa por política? Marque uma opção.

Codificação original: (1) Muito (2) Pouco (3) Nenhum interesse

Recodificação: (1) Nenhum interesse (2) Pouco (3) Muito

Variável: Ciclo social de conversa sobre política

Questão 4. Com que frequência você costuma conversar sobre estes assuntos políticos com: Marque uma opção.

Codificação original: (1) Frequentemente (2) Às vezes (3) Raramente (4) Nunca

\section{Variável: Posicionamento Ideológico}

Questão 32. Atualmente, fala-se muito sobre direita e esquerda na politica brasileira. $\mathrm{Na}$ escala abaixo o 1 corresponde a extrema esquerda e o 10 a extrema direita.

Codificação: Esquerda -1,2,3,4,5,6,7,8,9,10 Direita; (88) Não sei (99) Não quero responder

\section{Variável: Sentimento pelo país}

Questão11. Como você sabe existem várias coisas acontecendo no Brasil que faz com que existam sentimentos diferentes. Pensando nisso, qual é o sentimento que você tem nesse momento do país? Marque uma opção.

Codificação original: (1) Inseguro (2) Indignado (3) Assustado (4) Frustrado (5) Feliz (6) Confiante (7) Satisfeito (8) Seguro

Recodificação: (1): 1 a 4 - Sentimento negativo (2): 5 a 8 - Sentimento Positivo

\section{Variável: Sentimento por política}

Questão 23. Como você se sente com relação à política? Marque uma opção.

Codificação original: (1) Alienado (2) Indiferente (3) Desiludido (4) Interessado (5) Participativo

Recodificação: (1): 1 a 3 - Sentimento Negativo (2) - Sentimento Positivo

\section{Variável: Índice de Desafeição pela Política (IDP)}


222 | Renata A. de Oliveira, Carla S. Ayres, Jaqueline Resmini Hansen e Julian Borba

Questão 25. Atualmente se fala muito do que está acontecendo no país. Qual a sua opinião sobre as seguintes afirmaçóes: Marque uma opção.

25.1 Todos os politicos são corruptos.

25.2 Os politicos prometem, depois não cumprem.

25.3 Políticos são todos iguais.

Codificação original: (1) Concordo (2) Concordo em parte (3) Discordo

Recodificação: (0) Discordo (1) Concordo em parte (2) Concordo

Índice: Escala de 0 a 6

\section{Variável: Índice de Ineficácia Política (IIP)}

Questão 25. Atualmente se fala muito do que está acontecendo no país. Qual a sua opinião sobre as seguintes afirmaçóes: Marque uma opção.

25.5 Pessoas como as de minha familia não têm nenhuma influência nas açóes do governo.

25.6 Não adianta participar da politica, pois nunca muda nada.

25.7 Assuntos políticos são muito complicados pra mim, por isso não me interessam

Codificação original: (1) Concordo (2) Concordo em parte (3) Discordo

Recodificação: (0) Discordo (1) Concordo em parte (2) Concordo

Tabela 1 - Análise Fatorial- Dimensões da participação dos jovens nas capitais da Região Sul (2015-2016)

\begin{tabular}{|c|c|c|c|}
\hline & \multicolumn{3}{|c|}{ Fatores } \\
\hline & 1 & 2 & 3 \\
\hline Partidos Políticos & 035 & ,734 &,- 034 \\
\hline Reunióes Políticas & ,126 & ,786 & 135 \\
\hline Comícios Políticos & 070 & ,737 & 109 \\
\hline Associaçóes Comunitárias & ,366 & 252 &, 521 \\
\hline Atividades Religiosas & ,007 &,- 037 & 791 \\
\hline ONGs & ,382 & ,271 &, $400^{* * *}$ \\
\hline Orçamento Participativo & ,121 &, $335^{* *}$ &, 293 \\
\hline Abaixo Assinados & ,668 &, 085 & ,244 \\
\hline Manifestaçóes, protestos, passeatas & ,808 & ,046 &,- 021 \\
\hline Ocupaçōes de terrenos ou prédios públicos & ,375* & 374 &,- 291 \\
\hline Movimentos Sociais & ,786 & ,138 & ,036 \\
\hline Atividades no seu bairro & ,568 & ,047 & 361 \\
\hline \multirow[t]{2}{*}{ \% de Variação } & & $50,5 \%$ & \\
\hline & \multicolumn{3}{|c|}{ Fatores } \\
\hline Abaixo assinado via internet & & ,722 & \\
\hline Boicotes via internet & & ,749 & \\
\hline Twittaços & & ,730 & \\
\hline \% de variação & & $53,8 \%$ & \\
\hline
\end{tabular}

